\title{
Individual-based dispersal patterns of larval gobies in an estuary as indicated by otolith elemental fingerprints
}

\author{
MEI-YU CHANG ${ }^{1}$, CHIA-HUI WANG ${ }^{2}$, CHEN-FENG YOU ${ }^{3}$ and WANN-NIAN TZENG ${ }^{1}$ \\ ${ }^{1}$ Institute of Fisheries Sciences, College of Life Science, National Taiwan University, Taipei, Taiwan R.O.C. \\ E- mail: wnt@ntu.edu.tw \\ Institute of Biodiversity, National Cheng Kung University, Tainam, Taiwan R.O.C. \\ ${ }^{2}$ Department of Earth Sciences, National Cheng Kung University, Tainan, Taiwan R.O.C.
}

\begin{abstract}
SUMMARY: Otolith trace elements were used as natural tags to study the dispersal patterns of goby larvae in an estuary. Ninety-six larval gobies representing 10 species were collected in the estuary of Gongshytyan Creek in northwestern Taiwan in September 1997. Fifteen trace elements in fish otoliths were analysed with solution-based ICPMS. Trace elemental composition in otoliths differed significantly among the species. Habitat use by the larvae of the 10 species can be divided into four groups, based on principal component analysis of otolith elemental composition. All 10 goby species used the estuary as a nursery area irrespective of the fish being amphidromous or non-amphidromous. A part of the population may be lost during larval dispersal, as indicated from trace elemental composition recorded in the otolith.
\end{abstract}

Keywords: trace element, otolith, gobies, ICPMS, estuary, larval dispersal.

RESUMEN: PATRONES INDIVIDUALES DE DISPERSIÓN DE LARVAS DE GÓBIDOS EN UN ESTUARIO INDICADOS POR LA COMPOSICIÓN ELEMENTAL DE LOS OTOLITOS. - Se utilizó la composición elemental en los otolitos de larvas de góbidos como trazadores naturales para estudiar los patrones de dispersión en un estuario. Durante septiembre de 1997 se recolectaron 96 larvas de góbidos pertenecientes a 10 especies distintas en el estuario de Gongshytyan Creek situado en el noroeste de Taiwan. Se analizaron 15 elementos traza mediante espectroscopia de masas (ICPMS). La composición de elementos traza en los otolitos difirió significativamente entre especies. En base al Análisis de Componentes Principales de la composición elemental de los otolitos, los hábitats utilizados por las 10 especies pudieron dividirse en 4 grupos. Las 10 especies de góbidos usan el estuario como área de cría, independientemente de que las especies sean anfidromas o no-anfidromas. La composición elemental determinada para los otolitos analizados, permitió comprobar que una parte de la población puede ser perdida durante la dispersión larvaria.

Palabras clave: elementos traza, otolitos, góbidos, ICPMS, estuarios, dispersión larvaria.

\section{INTRODUCTION}

Gobies are among the most numerous species of estuarine fish. They represent approximately $10 \%$ of the total number of teleosts in the world (Nelson, 1994). As a consequence of physiological adaptations they have colonised nearly all marine and fresh waters. More than 190 species of gobies have been recorded in Taiwan, some of them widely dis- tributed in estuarine environments. Wootton (1984) defined the reproductive strategy of the goby as the overall pattern of reproduction typically shown by individuals in a species, and found that the reproductive tactics of the fish varied in response to variation in the environment. Gobies may be amphidromous or non-amphidromous according to their migratory behaviour and adult residential habitat. Amphidromous species spawn in freshwater, and 
the free embryos drift downstream to the sea where they undergo a planktonic larval stage and metamorphose into juveniles before returning to the rivers for growth and reproduction (McDowell, 1988, 1997). Non-amphidromous gobies do not migrate between freshwater and seawater but live in freshwater, estuaries or seawater throughout their life history. Estuaries may be important nursery grounds for larval gobies during their dispersal from spawning grounds. However, the dispersal manner and early life history of most goby species is not clear (Dotu and Mito, 1953; Dotu, 1955, 1961; Ryan, 1991; Katoh and Nishida, 1994; Shen, 1997; Shen et al., 1998). Thus, dispersal patterns of larval gobies are largely inferred from what is known of adults. Determination of microhabitat use by larval gobies is very important for fishery management and conservation, particularly in estuaries which are susceptible to pollution.

Use of the conventional mark-recapture method to track the migratory route of fish larvae across different environments is difficult, especially with external tags. Therefore, elemental composition in otoliths of fish has been widely used as a natural tag to study migration between environments (Radtke and Shepherd, 1991; Coutant and Chen, 1993; Dove and Kingsford, 1998; Wells et al., 2000). Otoliths can also be used to determine the age of larvae in days (Pannella, 1971). Thus, the chronology of the migratory environmental history of the fish can be reconstructed (Campana, 1999).

Otoliths are three pairs of aragonite crystal structures located in the inner ear of teleost fishes which function in balance and hearing. They are mainly composed of $\mathrm{CaCO}_{3}$ with a minor organic substrate. At least 31 trace elements have been found in otoliths (Campana, 1999). Otolith trace elements can be used as natural tags to track past migratory environmental history because the quality and quantity of the various elements in the otolith reflect the water mass chemistry the fish has experienced (Fowler et al., 1995; Gallahar and Kingsford, 1996). Therefore, otolith trace elements have been widely used to investigate stock affinity, habitat use, migratory life history, and connectivity among meta-populations (Campana et al., 1995, 1999, 2000; Gillanders and Kingsford, 1996; Kennedy et al., 1997, 2000, 2002; Morris et al., 2003; Wells et al., 2003). Trace elemental composition in otoliths can also be used to model larval dispersal from oceanographic features, to map phenotypic characters, and to locate and enumerate discrete spawning areas (Gillanders, 2002; Gillanders and Kingsford, 1996). There is evidence that elements such as $\mathrm{Ca}, \mathrm{Sr}$, and $\mathrm{Mg}$ show environmental profiles (reflecting salinity) (Tzeng, 1996; Bath et al., 2000; Milton and Chenery, 2001; Elsdon and Gillanders, 2003), while others such as $\mathrm{Ba}, \mathrm{Zn}$, and $\mathrm{Cd}$ show salinity and nutrient-type profiles (Bruland, 1983; Pender and Griffin, 1996; Bath et al., 2000; Alibert et al., 2003; Wells et al., 2003; Elsdon and Gillanders, 2003, 2005). However, Kraus and Secor (2004) suggested that the otolith $\mathrm{Sr}: \mathrm{Ca}$ ratio is determined by ambient water, and independent of salinity. $\mathrm{Hg}$ and $\mathrm{Pb}$ are generally associated with anthropogenic activity (Geffen et al., 1998). Trace elements in the otolith are thought to be taken up from the ambient water that fish have experienced, and then incorporated into the otolith through a complicated biogeochemical process with three interfaces, i.e. water-gill, blood-endolymph, and endolymph-crystal (Campana, 1999). A direct relationship between otolith composition and ambient water chemistry has been validated; however, the proportion of ion transport across membranes is under osmoregulatory control and is species-specific.

The purpose of this study was to distinguish the dispersal patterns of larval gobies in a Taiwanese estuary by otolith elemental fingerprinting with a high resolution solution-based inductively-coupled plasma mass spectrometer (ICPMS) to determine whether the microhabitat used by the larval gobies in the estuary differed among individuals and species. The larval dispersal process of gobies in the estuary is also addressed.

\section{MATERIALS AND METHODS}

\section{Sample collection}

Gobies were collected in the estuary of Gongshytyan Creek in northwestern Taiwan by fyke net during flood tide in September 1997 (Fig. 1). The net was set at the entrance to the estuary, facing the sea to catch the larval fishes that drift with the tidal current. Larval gobies were sorted from the larval fish collected by the net and immediately fixed with $95 \%$ alcohol. The gobies were identified to species and the 10 dominant species were selected for otolith trace elemental analysis. Total lengths were measured. Based on adult migratory behav- 


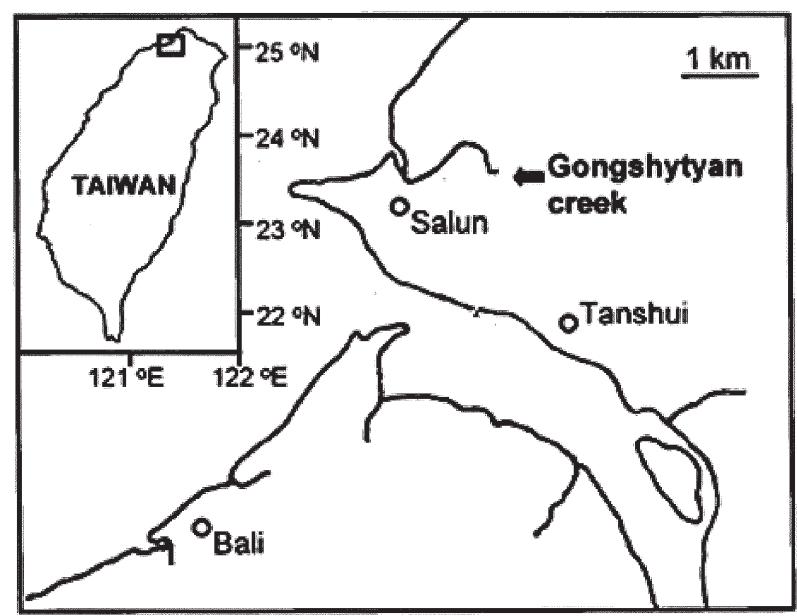

FIG. 1. - The sampling site of larval gobies in Gongshytyan Creek, northwestern Taiwan.

iour, the 10 species of larval gobies were classified as (1) amphidromous (Rhinogobius brunneus, $R$. giurinus, Sicyopterus japonicus, and Eleotris melanosoma), (2) non-amphidromous estuarine, (Bathygobius fuscus, Glossogobius biocellatus, Eleotris acanthopoma, Taenioides cirratus, and Scartelaos viridis), and (3) non-amphidromous marine (Mugilogobius tagala).

\section{SB- ICPMS analysis}

Sagittal otoliths of the larval gobies were extracted with glass probes under a microscope. All the otoliths were removed about one or two weeks before the ICPMS analysis. After removing adhering organic tissue by washing in double deionised (D.D.) water, one of the paired sagittal otoliths was stored in a vial; the other was prepared for solution- based inductively coupled plasma mass spectrometry (ICPMS) analysis. Cleaned otoliths were soaked with $\mathrm{H}_{2} \mathrm{O}_{2}$ in the vials using supersonic wave vibration for 5 minutes to wash out organic tissues, and triple-rinsed with D.D. water. Otoliths were dried overnight in an oven, and then weighed to the nearest $0.01 \mathrm{mg}$. Two $\mathrm{ml}$ of $0.3 \mathrm{~N} \mathrm{HNO}_{3}$ was added to the vial using supersonic wave vibration for 5 minutes to dissolve the otolith; the vial was then weighed to $0.01 \mathrm{~g}$ and subjected to supersonic wave vibration for at least 2 hours to ensure complete mixing. To meet the requirements of ICPMS, the otolith-dissolved solution was diluted to nearly $4 \mathrm{ppm}$ of $\mathrm{Ca}$ concentration.

Concentrations of 15 elements ( $\mathrm{Li}, \mathrm{Mg}, \mathrm{Ca}, \mathrm{Sr}$, $\mathrm{Sc}, \mathrm{Ba}, \mathrm{Pb}, \mathrm{Na}, \mathrm{Mn}, \mathrm{Fe}, \mathrm{Ni}, \mathrm{Cu}, \mathrm{Zn}, \mathrm{Y}$, and $\mathrm{K}$ ) were measurable by ICPMS. These elements were chosen because they can be detected steadily (exceeding detecting limit). $\mathrm{Na}$ and $\mathrm{K}$ were included in the analysis, because the interpretation of these metal elements may be compromised by metabolic activity. Concentrations of each element were calculated by running a standard solution prepared with known concentrations. An internal standard was also analysed after every 10 samples as a check against drift in intensity.

\section{Data analysis}

Raw ICPMS data on elements were back-calculated with total dilution factors to obtain absolute concentrations for each of the elements. Absolute concentrations were converted to weight percentage of the otolith to rank the relative abundance of ele-

TABLE 1. - Total length of the 10 species of larval gobies collected in the Gongshytyan Creek estuary in September 1997

\begin{tabular}{lccr}
\hline Species & Sample size & Total length (mm) & mean \pm SD \\
& & range & $11.125 \pm 1.200$ \\
1. Amphidromous spp. & 10 & $10.04-14.54$ & $7.512 \pm 0.664$ \\
Rhinogobius brunneus & 10 & $6.62-8.83$ & $11.579 \pm 1.657$ \\
Rhinogobius giurinus & 10 & $7.68-13.02$ & $7.232 \pm 0.782$ \\
Eleotris melanosoma & 4 & $6.16-9.01$ & \\
Sicyopterus japonicus & & & $6.847 \pm 0.899$ \\
& 12 & $5.66-8.98$ & $20.950 \pm 5.761$ \\
2. Non-amphidromous Estuarine spp. & 8 & $12.57-31.78$ & $6.473 \pm 0.859$ \\
Eleotris acanthopoma & 12 & $5.01-7.42$ & $14.731 \pm 2.502$ \\
Taenioides cirratus & 12 & $12.03-20.34$ & $16.780 \pm 1.210$ \\
Bathygobius fuscus & 9 & $13.41-18.48$ & $8.951 \pm 4.108$ \\
Glossogobius biocellatus & & & $5.65-16.8$ \\
Scartelaos viridis & 9 & & \\
3. Non-amphidromous Marine spp & & & \\
Mugilogobius tagala & & & \\
\hline
\end{tabular}




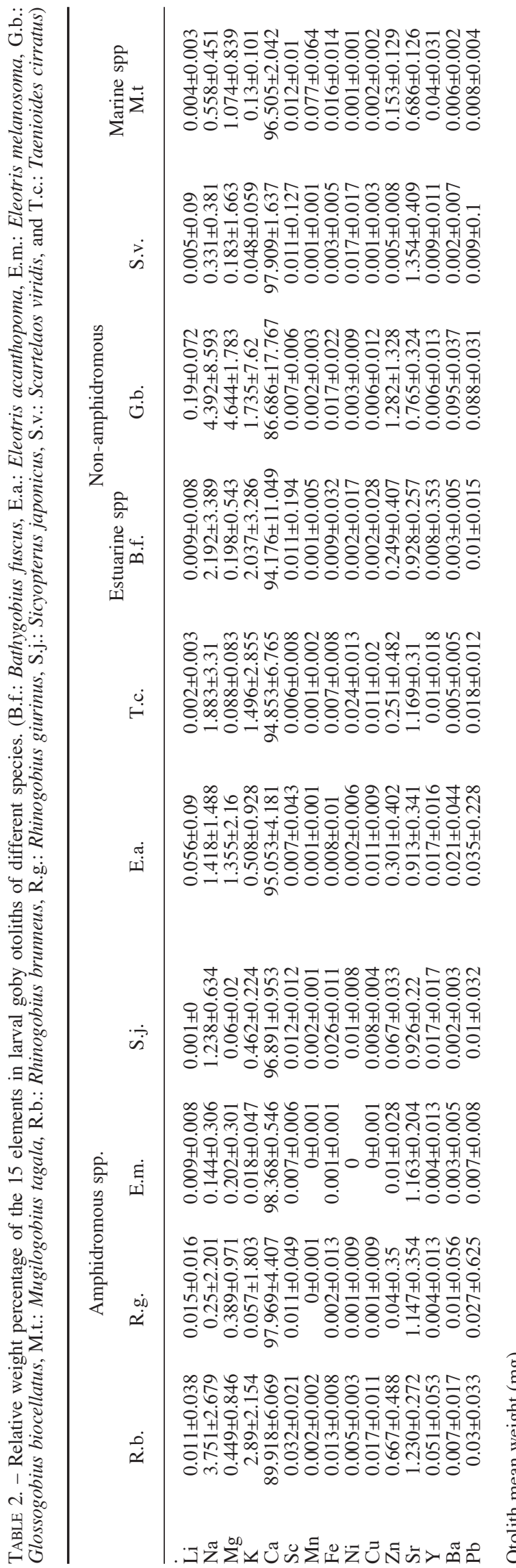

ments in the otolith. The ratio of each element to $\mathrm{Ca}$ in weight was used for statistical analysis. For each element, one-way ANOVA was used to test differences in concentration ratios among 10 goby species. All data were log-transformed to fit the normal distribution, and the relative contribution of the elements to the discrimination of different goby migratory types was evaluated by principal component analysis (PCA).

\section{RESULTS}

\section{Elemental composition in goby otoliths}

Calcium was the dominant component among the 15 elements measured in goby otoliths, but the weight percentage of calcium in otoliths differed among goby species (Tables 1,2 ). The lowest percentage of calcium in otoliths occurred in $G$. biocellatus. The proportion of the other 14 detectable elements also varied among species. Mean percentages of the 14 trace elements by weight in otoliths of the 10 species of larval gobies are presented in descending order (Fig. 2).

\section{Difference in element/Ca ratios among species}

One-way ANOVA indicated that among the 14 detectable elements, six element / Ca ratios $(\mathrm{Mg} / \mathrm{Ca}$, $\mathrm{K} / \mathrm{Ca}, \mathrm{Fe} / \mathrm{Ca}, \mathrm{Ni} / \mathrm{Ca}, \mathrm{Zn} / \mathrm{Ca}$, and $\mathrm{Sr} / \mathrm{Ca}$ ) were significantly different among the 10 species (Table 3 ). The difference in mean $( \pm 95 \%)$ element/Ca concentration ratios among the 10 species is shown in Figure 3 . Two of the amphidromous gobies, $R$. giurinus and $S$. japonicus, were distinct from others because of

TABLE 3. - The difference in element: Ca concentration ratios in otoliths among 10 species of larval goby by one-way ANOVA.

\begin{tabular}{lrrrr}
\hline & $\mathrm{MS}$ & $\mathrm{F}$ & $\mathrm{p}$ & \\
\hline $\mathrm{Li} / \mathrm{Ca}$ & 0 & 1.1189 & 0.3607 & \\
$\mathrm{Na} / \mathrm{Ca}$ & 0.000024 & 1.2936 & 0.2552 & $* *$ \\
$\mathrm{Mg} / \mathrm{Ca}$ & 0.000022 & 10.622 & 0 & $* *$ \\
$\mathrm{~K} / \mathrm{Ca}$ & 0.000005 & 3.5291 & 0.0011 & $*$ \\
$\mathrm{Mn} / \mathrm{Ca}$ & 0 & 1.0188 & 0.4334 & $* * *$ \\
$\mathrm{Fe} / \mathrm{Ca}$ & 0 & 5.0716 & 0.00002 & $* * *$ \\
$\mathrm{Ni} / \mathrm{Ca}$ & 0.000001 & 17.2248 & 0 & $* * *$ \\
$\mathrm{Cu} / \mathrm{Ca}$ & 0 & 1.4160 & 0.1972 & $* * *$ \\
$\mathrm{Zn} / \mathrm{Ca}$ & 0 & 5.7029 & 0.000006 & $* * *$ \\
$\mathrm{Sr} / \mathrm{Ca}$ & 0.001358 & 3.0069 & 0.0042 & $*$ \\
$\mathrm{Ba} / \mathrm{Ca}$ & 0 & 1.5560 & 0.1449 & \\
$\mathrm{~Pb} / \mathrm{Ca}$ & 0 & 1.9293 & 0.0608 & \\
& & & & \\
$*: \mathrm{p}<0.01, * *: \mathrm{p}<0.001, * * *: \mathrm{p}<0.0001$ & & &
\end{tabular}




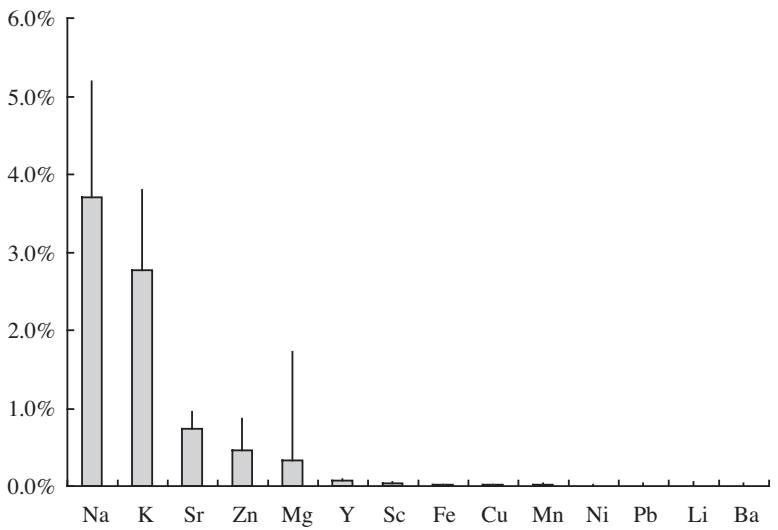

FIG. 2. - Mean $( \pm \mathrm{SD})$ weight of elements other than calcium as a percent of otolith weight in 10 species of larval goby.
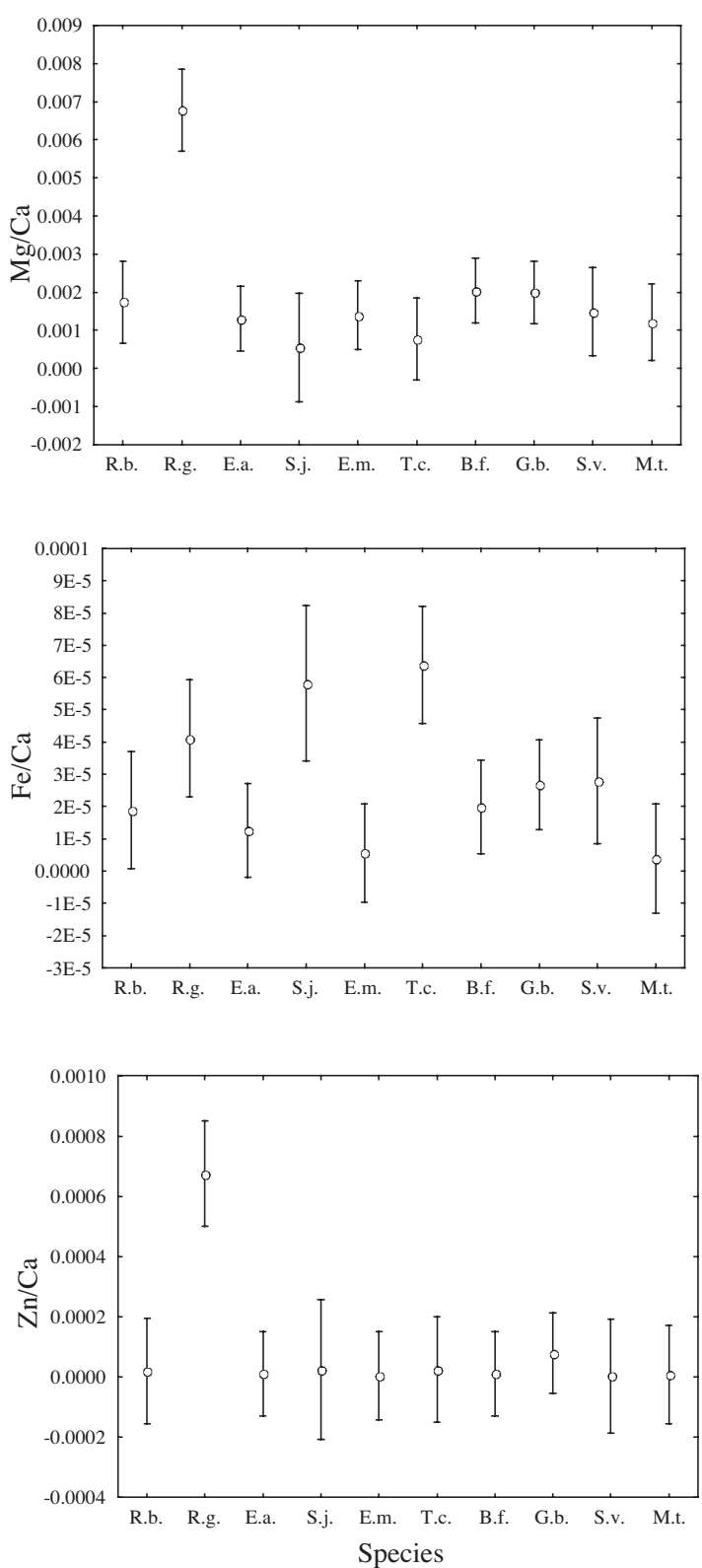

the higher concentration of $\mathrm{Mg}, \mathrm{K}, \mathrm{Fe}$, and $\mathrm{Zn}$ in the otoliths of $R$. giurinus and of $\mathrm{Fe}$ and $\mathrm{Ni}$ in the otoliths of S. japonicus (Fig. 3). Similarly, Ni and $\mathrm{Sr}$ were higher in T. cirratus. This indicates that the difference in element / Ca ratios in otoliths is speciesspecific.

\section{Discrimination of microhabitat use by otolith elemental composition}

PCA indicated that the 96 individuals of the 10 species of gobies could be classified into 4 groups by their otolith elemental composition. Most of the individuals of the 10 species had similar otolith
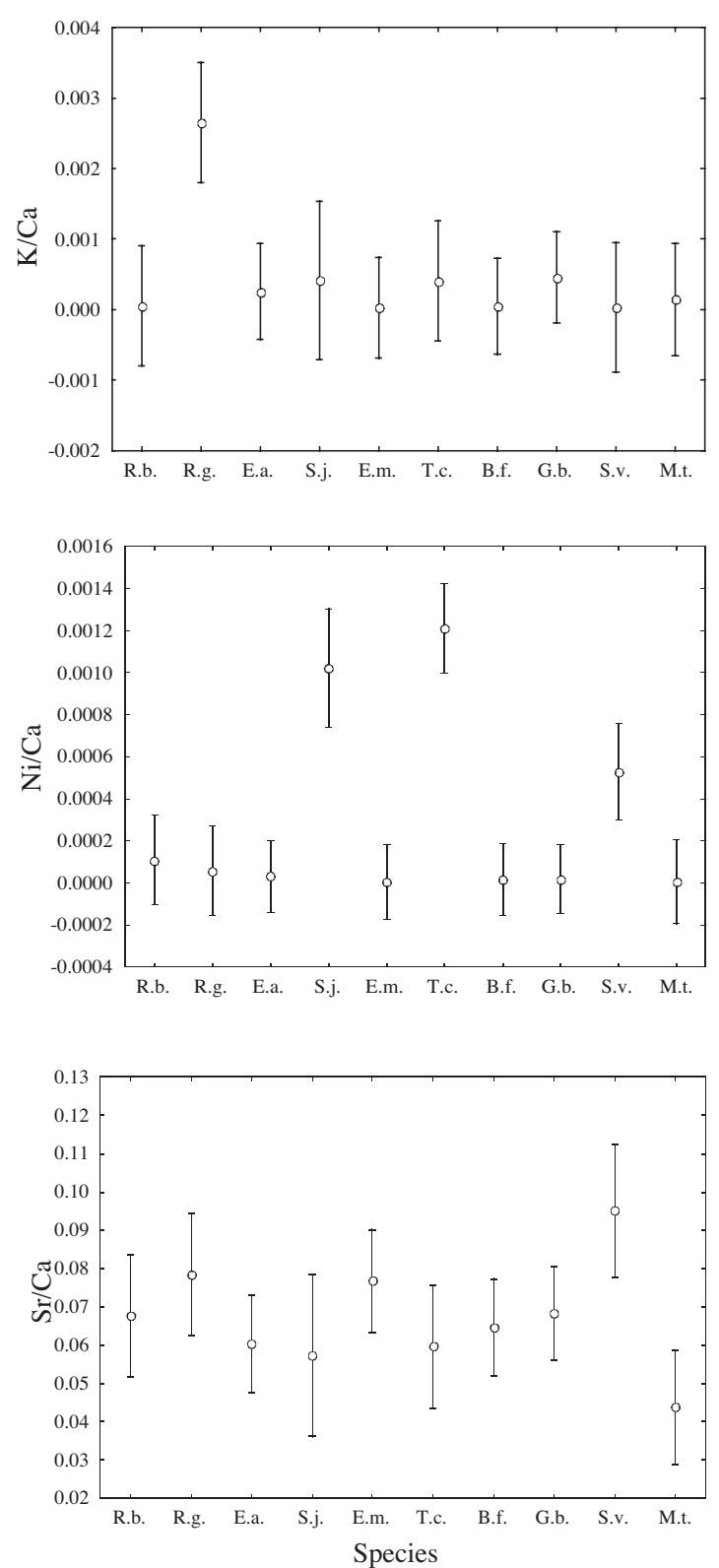

FIG. 3. - Comparison of the mean $( \pm 95 \%$ CI) concentration ratios of six elements to Ca in 10 goby species. 
170 • M. CHANG et al.
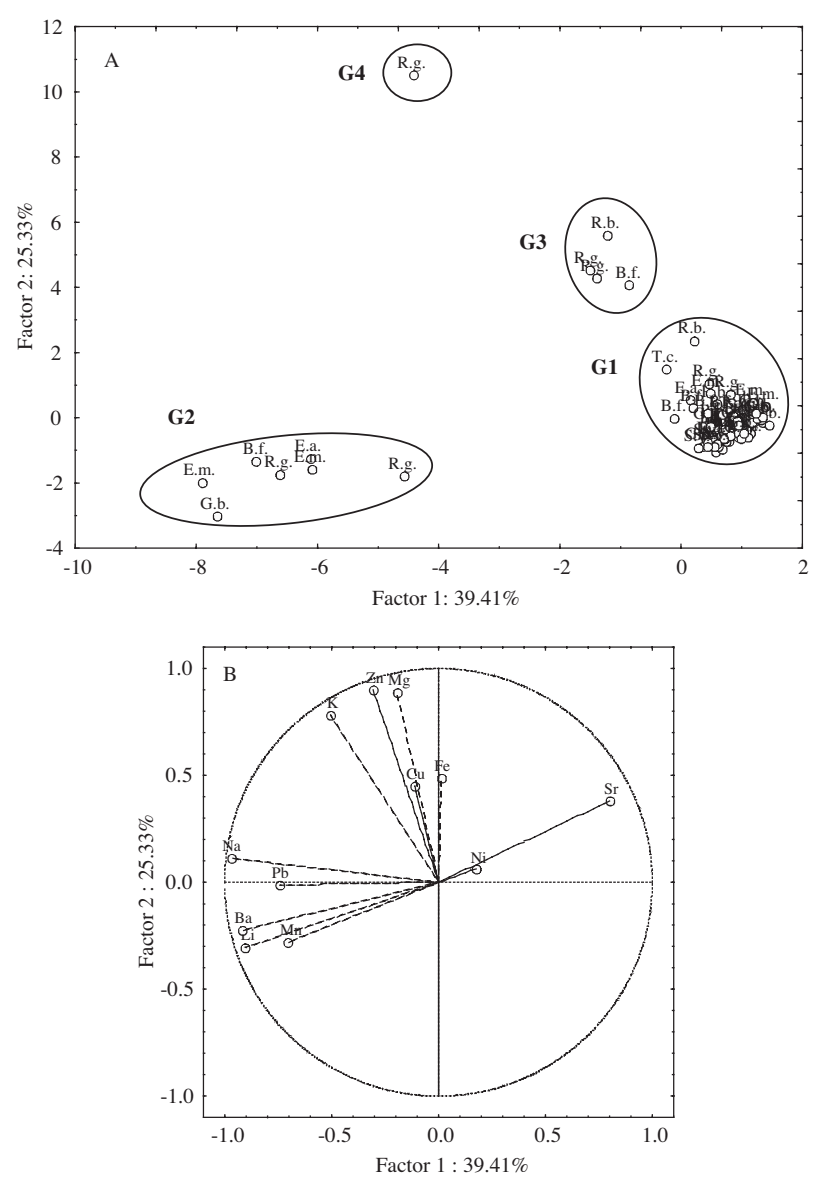

FIG. 4. - The grouping of 96 individuals of 10 species of gobies (A) classified by the relative contribution of the otolith element/Ca ratios in the first two components of PCA (B). See Table 2 for species abbreviations.
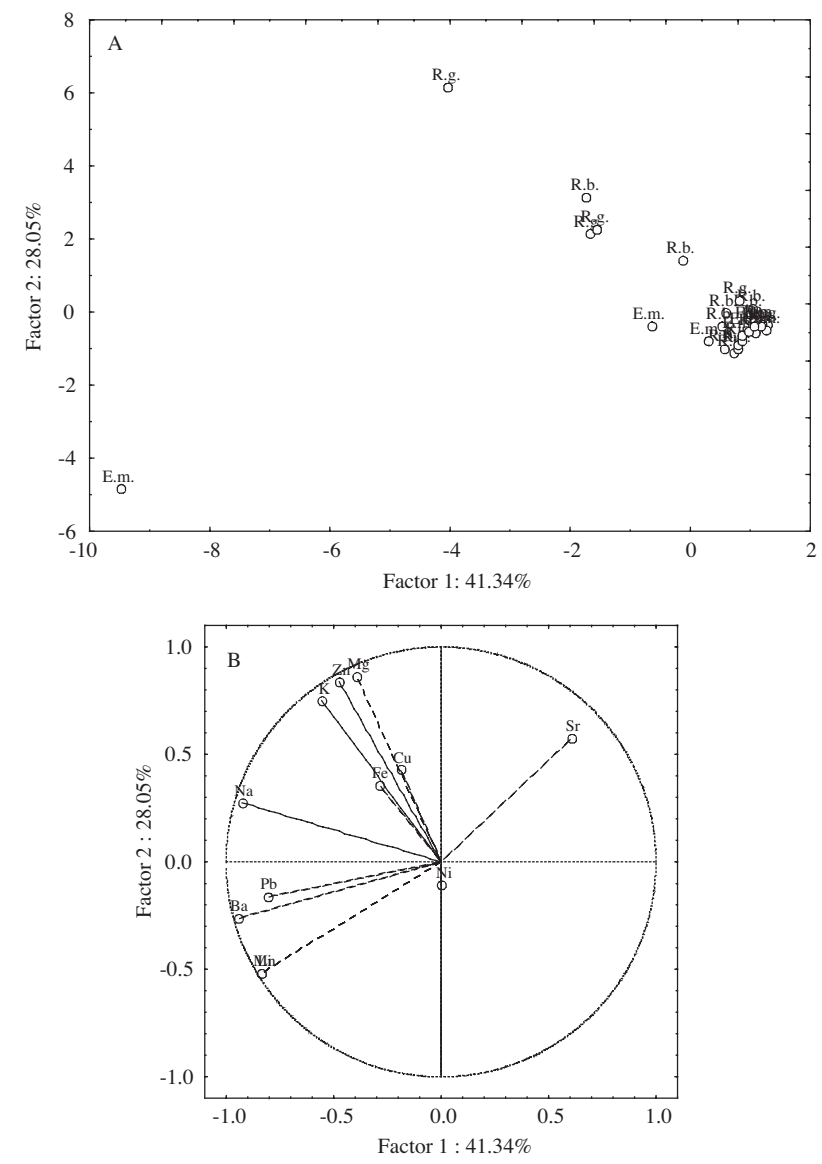

FIG. 5. - The grouping of 34 individuals of the 4 species of amphidromous larval gobies (A) classified by the relative contribution of the otolith element/Ca ratios in the first two components of PCA (B). See Table 2 for species abbreviations.

TABLE 4. - The species composition of gobies in each of the PCA groups in Figure 4 classified by otolith elemental composition.

\begin{tabular}{|c|c|c|c|c|c|}
\hline \multirow[t]{2}{*}{ Species } & \multirow[t]{2}{*}{ Sample size } & \multicolumn{4}{|c|}{ No. of fish } \\
\hline & & G1 & $\mathrm{G} 2$ & G3 & G4 \\
\hline \multicolumn{6}{|l|}{ 1. Amphidromous spp. } \\
\hline Rhinogobius brunneus & 10 & 9 & & 1 & \\
\hline Rhinogobius giurinus & 10 & 5 & 2 & 2 & 1 \\
\hline Eleotris melanosoma & 10 & 8 & 2 & & \\
\hline Sicyopterus japonicus & 4 & 4 & & & \\
\hline \multicolumn{6}{|c|}{ 2. Non-amphidromous Estuarine spp. } \\
\hline Eleotris acanthopoma & 12 & 11 & 1 & & \\
\hline Taenioides cirratus & 8 & 8 & & & \\
\hline Bathygobius fuscus & 12 & 10 & 1 & 1 & \\
\hline Glossogobius biocellatus & 12 & 11 & 1 & & \\
\hline Scartelaos viridis & 9 & 9 & & & \\
\hline \multicolumn{6}{|c|}{ 3. Non-amphidromous Marine spp } \\
\hline Mugilogobius tagala & 9 & 9 & & & \\
\hline Total & 96 & 84 & 7 & 4 & 1 \\
\hline
\end{tabular}


chemistry, which accounted for $87.5 \%$ of the total catch (G1 in Fig. 4A and Table 4). This implies that these 10 species used the same nursery area in the estuary. However, 10 individual $R$. giurrinus were distributed among the four groups, B. fuscus distributed from $\mathrm{G} 1$ to $\mathrm{G} 2$ and $\mathrm{G} 3, R$. brunneus from $\mathrm{G} 1$ to G3 and E. acanthopoma, E. melanosoma, and $G$. biocellatus from G1 to G2 (Table 4, Fig. 4A). The relative contribution of the element/Ca ratio to the grouping was different among groups (Fig. 4B). Na, $\mathrm{Ba}, \mathrm{Li}, \mathrm{Sr}, \mathrm{Pb}$, and $\mathrm{Mn}$ in PCA Factor one and $\mathrm{Zn}$, $\mathrm{Mg}$, and $\mathrm{K}$ in Factor two were the main contributors to the groupings. The cumulative contribution of the first two factors in the grouping accounted for 64.74\% (Fig. 4B).

Similarly, differences in habitat use of the individuals of the 4 amphidromous species (Fig. 5) and those of the 5 non-amphidromous species (Fig. 6) were also analysed using PCA. Results of these two new analyses also indicated that some individuals of these species have different habitat use, e.g. $R$. giurnus and $R$. brunneus were separated from the other two amphidromous species (Fig. 5), and the cumulative contribution of the first two factors in the grouping accounted for $69.39 \%$. Some individuals of E. acanthopoma could be distinguished from the other four non-amphidromous estuarine species of larval gobies by $\mathrm{Na}, \mathrm{Ba}, \mathrm{Pb}, \mathrm{Mn}$, and $\mathrm{Sr}$ in the first PCA axis (Fig. 6). The cumulative contribution of the first two factors of PCA in the grouping accounted for $65.84 \%$. This indicates that some individual goby larvae, even if classified according to the migratory pattern of the adult, emigrated from the main habitat of the fish.

\section{DISCUSSION}

A total of 31 elements have been detected in fish otoliths (Campana, 1999). The incorporation of elements into otoliths is physiologically and environmentally regulated. Water mass chemistry, temperature and growth rate of the fish are all thought to influence otolith elemental composition (Fowler et al., 1995; Farrel and Campana, 1996; Dove, 1997; Geffen et al., 1998; Campana, 1999; Bath et al., 2000; Milton and Chenery, 2001; Elsdon and Gillanders, 2005). Fifteen elements including the major elements $\mathrm{Ca}$ and $\mathrm{Na}$, the minor element $\mathrm{Sr}$, and 12 trace elements were detected in goby otoliths in this study. Among them, $6(\mathrm{Mg}, \mathrm{K}, \mathrm{Fe}, \mathrm{Ni}, \mathrm{Zn}$, and

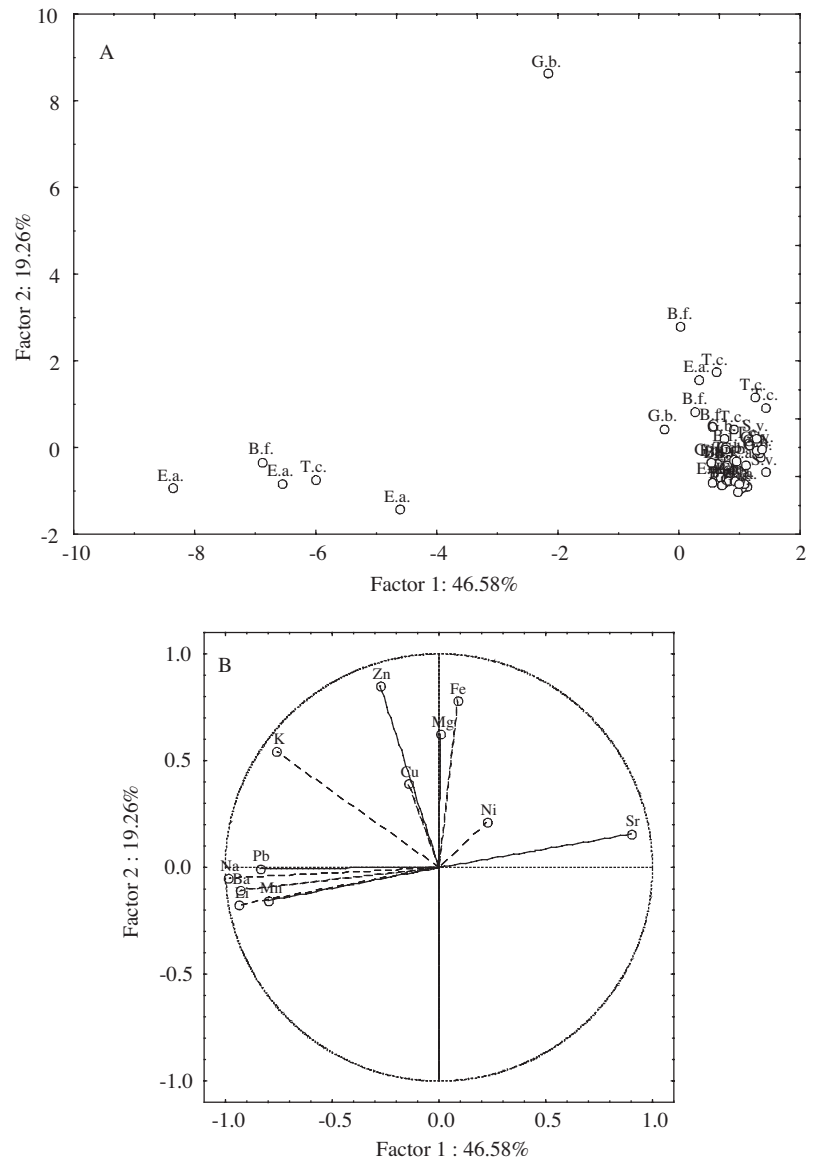

FIG. 6. - The result of PCA grouping of 53 individuals of the 5 species of non-amphidromous estuarine larval gobies (A) classified by the relative contribution of the otolith element/Ca ratios in the first two components of PCA (B). See Table 2 for species abbreviations.

Sr) were found to be significantly different among species. These elements are those that are mostly likely to serve as environmentally influenced stock markers. The elements in fish otoliths may be uptaken from water or from diets of different mineral composition (Hoff and Fuiman, 1995; Farrell and Campana, 1996; Milton and Chenery, 2001), which means that the environment that the fish inhabited is different. Elemental composition of otoliths has not only been used for stock identification, but also to reconstruct the habitat utilised in recent years (Gillanders and Kingsford, 1996; Campana, 1999; Thorrold et al., 2001). Type, abundance, and combination of elements can potentially be used to discriminate among groups of fish of different origins, as well as the water bodies they have inhabited (Elsdon and Gillanders, 2003). The signatures have been used to reconstruct environmental histories and migratory patterns of fish (Kafemann et al., 2000; Secor and Rooker, 2000; Tsukamoto and Arai, 2001). Thus, these elements in the goby's otoliths 
can tell us their past environmental history. The difference in otolith elemental composition of the goby is individual- and species-specific (Table 4), suggesting the dispersal pattern of the larvae toward the estuary varies, at least for some portion of the population. The higher concentrations of $\mathrm{Mg}$ and $\mathrm{Fe}$ in the otoliths of two non-amphidromous species might relate to level of primary production (Fig. 3), which is generally higher in the estuary. Sr, K, and Mg may also relate to salinity (Macintyre, 1970; Tzeng, 1996; Kawakami et al., 1998; Secor and Rooker, 2000). Ni and Zn may relate to anthropogenic effects. Hence otolith elemental fingerprints can provide insights into habitat use and dispersal pathways of larval gobies in the estuary.

The 14 element/Ca ratios in the otoliths of larval gobies cannot discriminate the migratory pattern of adult gobies, which are also divided into amphidromous and non-amphidromous (Table 1). This implies that the habitat use of the larvae is different from that of the adult, and that the same nursery area is used irrespective of species. It was also found that some individuals of some species dispersed away from the common habitat. Larval gobies passively move with the current from the spawning area to the nursery area (Jones, 1968). As indicated by the PCA grouping in Figs. 4-6, some vagrant individuals might have drifted away from the population's normal migratory circuit (see the vagrant-member hypothesis; Sinclair, 1998). Otolith fingerprints of the vagrant larvae may tell us their place of origin in comparison with most members of the population. However, we do not know what percentage of the larvae (vagrants) will be lost from the population.

The trace elements in the goby's otoliths, such as $\mathrm{Fe}, \mathrm{Zn}$, and $\mathrm{Ni}$, were quite low in concentration, but these elements played an important role in discerning the migratory environmental history of larval gobies. The incorporation of trace elements into the otolith is a very complicated biogeochemical process. There are few studies that have validated the effect of the environment on the elemental composition of fish otoliths. Concentrations of $\mathrm{Sr}$ and $\mathrm{Ba}$ in otoliths were found to be affected by concentrations of these elements in ambient water (Snyder et al., 1992; Brown and Harris, 1995; Schroder et al., 1995; Farrell and Campana, 1996; Bath et al., 2000; Elsdon and Gillanders, 2003). The concentration of $\mathrm{Mn}$ in fish otoliths may relate to physiological regulation or ontogenetic effects rather than to the abiotic environment (Elsdon and Gillanders, 2003).
According to previous studies and our results, the difference of elemental composition in otoliths of different species may be due to the different microhabitat use of gobies during the larval stage. Excluding G1, there were three groups of larval gobies which had experienced different ambient environments. These dispersed individuals might tell us that they left the original habitat and stayed at the edge of the population in the upper estuary, which was more affected by freshwater according to the results of PCA (Fig.4b). However, estuaries are mixing environments where water temperature, salinity and pH may vary in the course of a day. The habitat use of these larval gobies might be distinct because of different adaptations.

In conclusion, although most of the larval gobies used the estuary as a nursery area, otolith elemental fingerprints indicated that these sympatric gobies might have refined microhabitat use, which is not species-specific but fits with the vagrant-member hypothesis. In other words, the otolith elemental composition of the larvae indicated that most larvae have come from a similar environment, whereas a few larvae had otolith chemistries that were sufficiently different to suggest that they had developed elsewhere from the rest. The otolith elemental fingerprint is a powerful tool for classifying dispersal patterns of larval gobies. Further research will study the detailed early life history of gobies in order to interpret why otolith elemental composition differs among species.

\section{ACKNOWLEDGEMENT}

This study was financially supported by the National Science Council, Republic of China (Project No. NSC 93-2313-B002-054) and the Council of Agriculture, Republic of China (Project No. COA 94AS-14.1.1-FA-F1). The authors are grateful to Mr. Y.T. Wang for collecting and sorting the larvae, and to the anonymous reviewers and Dr. David Cairns, Department of Fisheries and Oceans, Canada for helpful comments on the early draft of the manuscript.

\section{REFERENCES}

Alibert, C., L. Kinsley, S.J. Fallon, M.T. McCulloch, R. Berkelmans and F. McAllister. - 2003. Source of trace element variability in Great Barrier Reef corals affected by the Burdekin 
flood plumes Geochim Cosmochim. Acta. 67: 231-246.

Bath, G.E., S.R. Thorrold, C.M. Jones, S.E. Campana, J.W. McLaren and J.W.H. Lam. - 2000. Strontium and barium uptake in aragonitic otoliths of marine fish. Geochim. Cosmochim. Acta., 64: 1705-1714.

Brown, P. and J.H. Harris. - 1995. Strontium batch-marking of golden perch (Macquaria ambigua Richardson) and trout cod (Maccullochella macquariensis Cuvier). In: D.H. Secor, J.M. Dean and S.E. Campana (eds.), Recent developments in fish otolith, pp. 693-701. Research. University of South Carolina Press, Columbia.

Bruland, K.W. - 1983. Trace elements in sea-water. Chem. Oceanogr., 8: 157-220.

Campana, S.E. - 1999. Chemistry and composition of fish otoliths: pathway, mechanisms and applications. Mar. Ecol. Prog. Ser., 188: 263-297.

Campana, S.E., J.A. Gagne and J.W. Mclaren. - 1995. Elemental fingerprinting of fish otoliths using ID-ICPMS. Mar. Ecol. Prog. Ser., 122: 115-120.

Campana, S.E., G.A. Chouinard, J.M. Hanson and A. Frechet. 1999. Mixing and migration of overwintering cod stocks near the mouth of the Gulf of St. Lawrence. Can. J. Fish. Aquat. Sci., 56: $1873-1881$.

Campana, S.E., G.A. Chouinard, J.M. Hanson, A. Frechet and J. Brattery. - 2000. Otolith elemental fingerprints as biological tracers of fish stocks. Fish. Res. 46: 343-357.

Coutant, C.C. and C.H. Chen. - 1993. Strontium microstructure on scales of freshwater and estuarine striped bass Morone saxatilis detected by laster ablation mass spectrometry, Can. J. Fish. Aquat. Sci., 50: 1318-1323.

Dotu, Y. - 1955. The life history of a goby, Chaenogobius urotarnia (Hilgendorf). Sci. Bull. Fac. Agr., Kyushu Univ., 15: 367374. (In Japanese, English abstract)

Dotu, Y. - 1961. The binomics and life history of the gobioid fish, Rhinogobius giurinus (Rutter). Bull. Fac. Fish., Nagasaki Univ., 10: 120-126. (In Japanese, English abstract)

Dotu, Y. and S. Mito. - 1953. Life history of a gobioid fish, Sicydium japonicus Tanaka. Sci. Bull. Fac. Agr., Kyushu Univ., 15: 213-221. (In Japanese, English abstract)

Dove, S.G. - 1997. The incorporation of trace metals into the eye lenses and otoliths of fish. Ph.D. thesis, Univ. Sydney, Australia.

Dove, S.G. and M.J. Kingsford. - 1998. Use of otolith and eyelenses for measuring trace-metal incorporation in fishes - a biogeographic study. Mar. Biol., 103: 377-387.

Elsdon, T.S. and B.M. Gillanders. - 2003. Relationship between water and otolith elemental concentrations in juvenile fish, Acanthopagrus butcheri. Mar. Ecol. Prog. Ser., 260: 263-272.

Elsdon, T.E. and B.M. Gillanders. - 2005. Alternative life-history patterns of estuarine fish: Barium in otoliths elucidates freshwater residency. Can. J. Fish. Aquat. Sci., 62: 1143-1152.

Farrell, J. and S.E. Campana. - 1996. Regulation of calcium and strontium deposition on the otolith of juvenile tilapia, Oreochromis niloticus. Comp. Biochem. Physiol., 115: 103109.

Fowler, A.J., S.E. Campana, C.M. Jones and S.R. Torrold. - 1995 Experimental assessment of the effect of temperature and salinity on elemental composition of otoliths using solution-based ICPMS. Can. J. Fish. Aquat. Sci., 52: 1421-1430.

Gallahar, N.K. and M.J. Kingsford. - 1996. Factors influencing $\mathrm{Sr} / \mathrm{Ca}$ ratios in otoliths of Girella elevata: an experimenta investigation. J. Fish Biol., 48: 174-186.

Geffen, A.J., N.J.G. Pearce and W.T. Perkins. - 1998. Metal concentration in fish otoliths in relation to body composition after laboratory exposure to mercury and lead. Mar. Ecol. Prog. Ser. 165: 235-245.

Gillanders, B.M. - 2002. Connectivity between juvenile and adult fish populations: do adults remain near their recruitment estuaries? Mar. Ecol. Prog. Ser., 240: 215-223.

Gillanders, B.M. and M.J. Kinsford. - 1996. Elements in otoliths may elucidate the contribution of estuarine recruitment to sustaining coastal reef populations of a temperate reef fish. Mar. Ecol. Prog. Ser., 141: 13-20.

Hoff, G.R. and L.A. Fuiman. - 1995. Environmentally induced variation in elemental composition of red drum (Sciaenops ocellatus) otoliths. Bull. Mar. Sci., 56: 578-591.

Jones, R.S. - 1968. Ecological relationships on Hawaiian and
Johnston Island Acanthuridae (Surgeonfishes). Micronesca, 4; 309-361.

Kafemann, R.,S. Adlerstein and R. Neukamm. - 2000. Variation in otolith strontium and calcium ratios as an indicator of life history strategies of freshwater species within a brackish water system. Fish Res., 46: 313-325

Katoh, M. and N. Nishida. - 1994. Biochemical and egg size evolution of freshwater fishes in the Rhinogobius brunneus complex (Pisces, Gobiidae) in Okinawa, Janpan. Biol. J. Linn. Soc., 51: 325-335.

Kawakami, Y.,N. Mochioka, K. Morishita, T. Tajima, H. Nakagawa, H. Toh and A. Nakazono. - 1998. Factors influencing otolith strontium/ calcium ratios in Anguilla japonica elvers. Environ. Biol. Fish., 52: 299-303.

Kennedy, B.D., C.L. Folt, J.D. Blum and C.P. Chamberlain. -1997. Natural isotope markers in salmon. Nature, 387: 766-767.

Kennedy, B.P., J.D. Blum, C.L. Folt and K.H. Nislow. - 2000. Using natural strontium isotopic signatures as fish markers: methodology and application, Can. J. Fish. Aquat. Sci., 57: 2280-2292.

Kennedy, B.P., A. Klaue, J.D. Blum, C.L. Folt and K.H. Nislow. 2002. Reconstructing the lives of fish using $\mathrm{Sr}$ isotopes in otoliths. Can. J. Fish. Aquat. Sci., 59: 925-929.

Karus R.T. and D.H. Secor. - 2004. Incorporation of strontium into otoliths of an estuarine fish. J. Exp. Mar. Ecol., 302: 85-106.

Macintyre, F. - 1970. Geochemical fractionation during mass transfer from sea to air by breaking bubbles. Tellus, 22: 451.

McDowall, R.M. - 1988. Diadromy in fishes: Migration between freshwater and marine environments. London: Croom- Helm.

McDowall, R.M. - 1997. Is there such a thing as amphidromy? Micronesica, 30: 3-14.

Milton, D.A. and S.R. Chenery. - 2001. Sources and uptake of trace metal in otoliths of juvenile barramundi (Lates calcarifer). $J$. Exp. Mar. Biol. Ecol., 264: 47-65.

Morris, J.A., R.A. Rulifson and L.H. Toburen. - 2003. Life history strategies of striped bass, Morone saxatilis, populations inferred from otolith microchemistry. Fish. Res., 62: 53-63.

Nelson, J.S. - 1994. Fishes of the world. John Wiley, New York.

Pannella, G. - 1971. Fish otoliths: daily growth layers and periodical patterns. Science, 173(4002): 1124-1127.

Pender, P.J. and R.K. Griffin. - 1996. Habitat history of barramundi Lates calcarifer in a North Australian river system based on barium and strontium levels in scales. Trans. Am. Fish. Soc., 125: 679.689

Radtke, R.L. and B.S. Shepherd. - 1991. Current methodological refinements for the acquisition of life history information in fishes: paradigms from pan- oceanic billfishes. Comp. Biochem. Physiol. A., 100: 323-333.

Ryan P.A. - 1991. The success of the Gobiidae in tropical Pacific insular streams. New Zealand J. Mar. Freshw. Res., 18: 25-30.

Schroder, S., C. Knudsen and E. Volk. - 1995. Marking salmon fry with strontium chloride solutions. Can. J. Fish. Aquat. Sci., 52: 1141-1149.

Secor, D.H. and J.R. Rooker. - 2000. Is otolith strontium a useful scalar of life cycles in estuarine fishes? Fish. Res., 46: 359-371.

Sinclair, M. - 1988. Marine Populations. An essay on population regulation and speciation. J. Anim. Ecol., 59 (Suppl. 2): 800801.

Shen, K.N. - 1997. Early life history and recruitment dynamics of amphidromous goby Sicyopterus japonicus. Master's thesis, Institute of Fishery Science, National Taiwan University.

Shen, K.N., Y.C. Lee and W.N. Tzeng. - 1998. Use of otolith microchemistry to investigate the life history pattern of gobies in a Taiwanese stream. Zool. Stud., 37(Suppl. 4): 322-329.

Snyder, R.J., B.A. McKeown, K. Colbow and R. Brown. - 1992. Use of dissolved strontium in scale marking of juvenile salmonids: effect of concentration and exposure time. Can.J. Fish. Aquat. Sci., 49: 780-782.

Thorrold, S.R., C. Latkoczy, P.K. Swart and C.M. Jones. - 2001. Natal homing in a marine fish metapopulation. Science, 291: 297-299.

Tsukamoto, D.W. and T. Arai. - 2001. Facultative catadromy of the eel Anguilla japonica between freshwater and seawater habitats. Mar. Ecol. Prog. Ser., 119: 37-44.

Tzeng, W.N. - 1996. Effects of salinity and ontogenetic movements on strontium: calcium ratios in the otoliths of the Japanese eel, Anguilla japonica Temminck and Schlegel. J. Exp. Mar. Biol. 
$174 \cdot$ M. CHANG et al.

Ecol., 199: 111-122.

Wells, B.K., G.E. Bath, S.R. Torrold, and C.M. Jones. - 2000. Incorporation of strontium, cadmium, and barium in juvenile spot (Leiostomus xanthurus) scales reflects water chemistry. Can. J. Fish. Aquat. Sci., 57: 2122-2129.

Wells, B.K., B.E. Rieman, J.L. Clayton, D.L. Horan, and C.M. Jones. - 2003. Relationships between water, otolith, and scale chemistries of westslope cutthroat trout from the Coeur d' Alene River, Idaho: The potential application of hard-part chemistry to describe movements in freshwater. Trans. Am. Fish. Soc., 132: 409-424.

Wootton, R.J. - 1984. Introduction: strategies and tactics in fish reproduction. In: G. W. Potts, and R. J.Wootton (eds.), Fish Reproduction: Stretegies and Tactics, pp.1-13. London: Academic Press.

Received November 2, 2005. Accepted May 8, 2006.

Published online September 28, 2006. 